\title{
Rural Energy Demand and Climate Change Adaptation in Ghana
}

\author{
Kwabena Boafo Adom-Opare (Corresponding Author) \\ World Bank - ECREEE ROGEP ${ }^{1}$ \\ One Airport Square, $8^{\text {th }}$ Floor, Airport City, P.O. Box 5374 \\ Cantonment, Accra, Ghana
}

Tel: 233246253 436. E-mail: adomoparekb@gmail.com

Daniel Kweku Baah Inkoom

Kwame Nkrumah University of Science and Technology

Department of Planning, Kumasi, Ghana

E-mail: dinkoom@gmail.com

Received: February 26, 2017 Accepted: March 9, 2017 Published: December 22, 2017 doi:10.5296/jpmr.v3i2.10837～URL: http://dx.doi.org/10.5296/jpmr.v3i2.10837

\begin{abstract}
This paper applies a cross-sectional and prospective study designs to explore the nexus between energy forms in rural areas in Ghana and prevailing climate change impact indicators. The results indicate that rural energy forms in Ghana are mainly fuel wood and charcoal, with limited number of modern energy forms. These dominant energy forms affect and are affected by climate indices that were studied in this paper; which were rainfall, surface temperature and evaporation. There is continual increase in demand for fuel wood and charcoal across different altitude and economic zones in rural communities and this phenomenon will continue even with increased access to modern energy forms like electricity and LPG. The analysis also shows that with increasing demand and slow forest cover regeneration; there was a deficit in fuel wood supply even though there is surplus charcoal supply. This phenomenon threatens energy access and climate change in rural communities.
\end{abstract}

Keywords: Climate Change, Fuel wood, Charcoal, Adaptation

\footnotetext{
${ }^{1}$ Current affiliation and World Bank - ECREEE Regional Off-Grid Electrification Project (ROGEP) holds no claims or endorses contents of this work
} 


\section{Introduction}

The Intergovernmental Panel on Climate Change [IPCC] (2005) notes that climate change would impact energy supply and demand. Although renewable energy sources may be adaptable to changes in the weather pattern and a longer term climate change, a larger percentage of Ghana's energy sources in rural communities which are renewable in nature make it relatively more vulnerable to climate change. Biomass and hydropower generation are the energy sources that are most likely to be affected most due to its sensitive nature to the amount, timing, and geographical pattern of precipitation as well as temperature (Thiam, 2009). The heavy reliance on biomass is mostly likely to either remain at very high levels or even grow over the next few decades (AFREA, 2011).

Adaption to climate change provides a good avenue to maintain a sustainable energy mechanism when looking at the over reliance on biomass and how climate change is expected to affect it. A surge in interest in adaptation action is not without precedent (IPCC, 2005).Since the beginning of the century, adaptation has been talked of and has been used in many instances. Smithers and Smit points out that, in trying to define the scope in which adaptation operates, questions have been raised as to whether the process of adaptation is the development of technological changes that maintain current life styles, or implies the actual behavioral adjustments needed to adapt livelihoods to new climatic conditions (Smithers and Smit, 1997). It is very important to mention here that, though adaptation is considered, it does not go without measures towards mitigation. However, for purposes of this paper, adaption is looked at exclusively.

In perspective, this paper tries to explore the linkages between rural energy sources in Ghana and climate change in trying to find a balance for achieving adaptation in order to secure rural energy sources.

\section{Discussion of the Problem}

Rural community development in Ghana faces several challenges ranging from population growth to economic factors and today, the impacts of climate change. No state, not even one that is among the strongest, is capable of guaranteeing the complete mitigation of climate change impacts (Mosha, 2011). The problem this paper tries to explore is the increasing rate of reduction of energy supply stock in Ghana's rural communities and the increasing threats of climate change.

These problems are made very difficult to solve when climate change data show very scaring trends of events. For example, between 2005 and 2010, Ghana's forest cover reduced annually by $2.19 \%$ and the greenhouse gas (GHG) emissions increased from 55.94MtCO2e to $58.71 \mathrm{MtCO} 2 \mathrm{e}$ (WRI, 2010). Though these figures are very low compared to countries like China, India and the USA who recorded averagely 6700MtCO2e in 2010, Ghana's figures are relatively high compared to its development growth and ability adapt to climate change. Table 1 compares the relative emission of carbon between Ghana and other selected countries. 
Table 1. Carbon Emission Indices for 2010

\begin{tabular}{|c|c|c|c|}
\hline Country & $\begin{array}{c}\text { Total GHG Emissions } \\
(\mathrm{MtCO} 2 \mathrm{e})^{2}\end{array}$ & $\begin{array}{l}\text { Total GHG Emissions Per } \\
\text { GDP PPP } \\
\text { (tCO2e/million \$ GDP) }\end{array}$ & $\begin{array}{l}\text { Total emissions per } \\
\text { capita }^{4} \\
\text { (tCO2e per capita) }\end{array}$ \\
\hline China & 10081.53 & 1138.49 & 7.76 \\
\hline India & 2304.39 & 618.09 & 1.93 \\
\hline Mexico & 706.46 & 487.36 & 5.84 \\
\hline Nigeria & 490.17 & 915.58 & 1.94 \\
\hline Ghana & 58.71 & 724.48 & 1.08 \\
\hline Liberia & 16.48 & 833.81 & 0.41 \\
\hline
\end{tabular}

Source: WRI, 2010

Although Ghana's emission rates are lower than the world's leading emitters, its emission per GDP growth is significantly high, meaning more emissions are recorded per the developments that occur. Climate change could poses challenges to the existing problems in the rural energy context.

\subsection{Impacts of Climate Change in Ghana; Retrospective Look in the recent past}

The impacts of climate change have been more evident in forest reserves, agriculture, water bodies, rainfall and temperature, migration and energy (IPCC, 2009 and Inkoom, 2011). The forest cover has depleted by $50 \%$ between 1970 and 1990 and further away from 1990 to 2009, it decreased by 86 \%, from 8.6 million hectares to 1.2 million hectares (Inkoom, 2011). This phenomenon has been as a result of deforestation, physical developments and the lack of rainfall to help forest reconstruct itself naturally from tree cutting (IPCC, 2009). Temperatures are rising and Ghana has already experienced an increase in temperatures by $1^{\circ} \mathrm{C}$ over the past 30 years (Cameron, 2011).

The increase in sea level which was recorded at $0.06 \mathrm{~m}$ in 2010 (Inkoom, 2011) has caused frequent flooding and introducing more waterborne diseases into the country, especially for communities along the coast. Big cities are mostly vulnerable to flooding in Ghana due to poor waste and drainage systems and uncontrolled development. Kumasi and Accra are recent cases of flooding. For example, the 2011cholera outbreak in the country was attributed to the massive flooding and contamination of water sources as well as food sources. Also, the 2007 flooding in the north shows clearly the impacts climate change is having on the country; more than 317,000 people were affected with 30 dead, $100 \mathrm{~km}$ of roads destroyed, 210 schools and 45 health centers were damaged and more than 630 drinking water facilities were contaminated/destroyed (MEST, 2010).

In addition, the recorded droughts in 1983, 1994 and most recent 2001 caused the Akosombo and Kpong dams to generate low volumes of electricity demanded and Ghana was forced to

\footnotetext{
${ }^{2}$ Including Land Use Change and Forestry (LUCF)

${ }^{3}$ Excluding LUCF

${ }^{4}$ Excluding LUCF
} 
share the little power supply (IPCC, 2009). In the first quarter of 2014, the Akosombo and Bui dams have experienced low volumes of water flowing into the turbines and this has caused the Electricity companies and regulatory authorities to cut down on electricity supply. Climate change impacts on energy sources are greater given Ghana's low ability to response to these shocks.

\subsection{Rural Energy in Ghana}

Before the beginning of the $21^{\text {st }}$ century, rural communities in developing countries were consuming almost $40 \%$ of total energy consumption and their energy-use patterns center around wood-based biomass specifically fuel wood and charcoal (Bhagavan and Karekezi, 1992). Currently in rural Ghana, it is estimated that about $84 \%$ of households use fuel wood for cooking and a further $13 \%$ depend on charcoal while the remaining $3 \%$ includes all other sources, such as electricity, kerosene and LPG (KITE, 2008).

Generally, the majority of Ghana's energy use is from biomass in the form of firewood and charcoal. These two account for about 59\% of the total energy consumption with petroleum products and electricity constituting 32\% and 9\% respectively (Energy Commission, 2011). According to the Energy Commission, an estimated total of 20 million tons of wood fuel and charcoal is consumed annually and the rural consumption averages the majority.

\section{Methods}

The issues and data that will be discussed in this paper are based on the field study conducted in the Nzema East Municipal Assembly (NEMA) - a predominantly rural district in Western Region of Ghana which makes a case for selection. Nine (9) communities in the NEMA were sampled - Kutukrom, Gwira Banso, Gwira Eshiem, Bamiankor, Anibil, Dominase, Aguafo, Nsien and Edelesuazo.

The study was conducted based on cross-sectional and prospective designs. Data were mainly collected using structured interview questionnaires, focus group discussion and climate interview guides. Energy sources data were collected in terms of residential and industrial purpose and further into cooking, lighting, ironing, baking and/or other industrial activities. Data on energy consumption were measured in weight quantity (kg) and used Ghana's average measurements for bag of charcoal and a bag of fuel wood as $50 \mathrm{~kg}$ and $40 \mathrm{~kg}$ respectively. Climate change data were rather difficult to obtain and measure. For this reason, secondary data was used mostly as collected from the meteorological service department. A permutation of univariate descriptive, bivariate descriptive, inferential and narrative analyses was used to analyze data.

\section{Data and Analysis}

\subsection{Energy Forms in Rural Communities}

Rural livelihoods are mostly characterized by poor access to modern energy sources and over-reliance on traditional biomass, especially wood fuels (Thiam, 2009). All the selected communities have access to fuel wood and charcoal (Adom-Opare, 2012). The breakdown of available energy sources are shown in figure 4. 


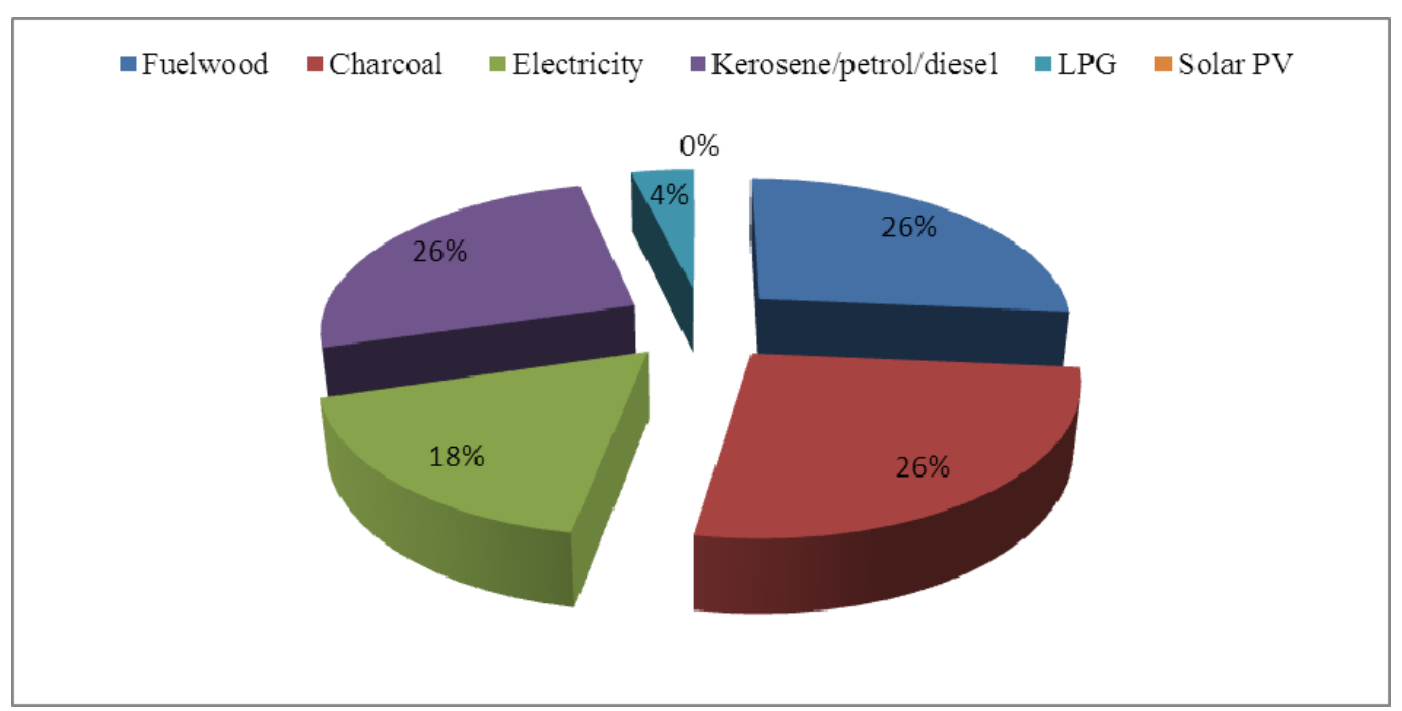

Figure 1. Energy Forms Available in Nzema East Rural

Source: Adom-Opare, 2012

Relative to the national averages of rural energy forms, NEMA has little access to electricity and LPG. The national figures show that 33\% have access to electricity and 14\% have access to LPG (Energy Commission, 2012) compared to $18 \%$ and $4 \%$ respectively in NEMA. The indication here is that, people in NEMA will depend and use more wood fuels which are in "abundance" as compared to more modern forms.

4.1.2 Energy Forms at different altitudes in Rural Communities

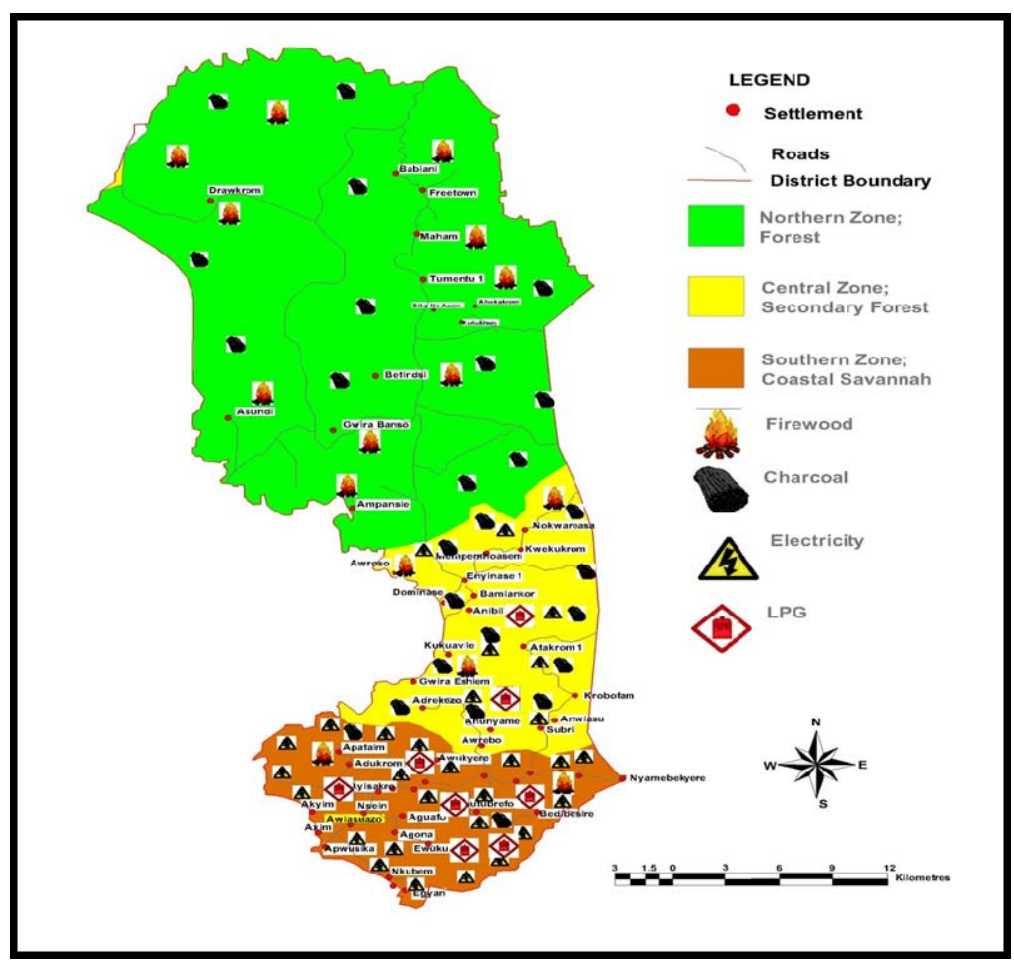

Figure 5. Variations in energy forms across different geographies

Source: Adom-Opare, 2012 
The study showed that, at various altitudes in NEAM, energy sources and use differed. Ecological and socio-economic conditions vary in a given context whether national, regional or local. The study identifies these variations and put them into 3 zones; the coastal savannah, the secondary forest and the moist deciduous forest zones.

In summary, the fuel wood consumption rate remained the same throughout all three zones, but the rate of charcoal use oscillated across the different areas. It was realized that, in the northern parts where access to large forests were available, the use of charcoal was very minimal; and even though there was no physical access to some modern energy forms (electricity and LPG), households had the economic ability to acquire them, but remained reliant on the traditional ones due to its abundance. It should be said here that, this attitude could lead to higher demand on forest resources to satisfy household energy needs.

Although the picture we get from such data is not conclusive, one gets an idea of the importance of wood fuel and charcoal, as well as the rural energy situation in NEMA and Ghana. This pattern is not likely to change in the next several decades, with dire consequences on natural forests which supply rural households with wood fuels and charcoal.

\subsection{Rural Energy Demand and Supply Nexus}

In trying to find the balance between energy demand and supply, the study calculates the energy consumption rates in terms of kilograms per day ( $\mathrm{kg} /$ day) for both fuel wood and charcoal in the residential and commercial sectors. Because the study is exploring the balance between rural energy (which study identified to be mainly fuel wood based) and climate change, the use of kg/day energy consumption calculation was used.

As identified in the previous sections, residential energy demand is mainly fuel wood based, but in contrast, more than 64\% of commercial energy demand and consumption was electricity and LPG sources. This was as a result of the nature of the commercial activity they were engaged in; which were mainly groceries shops, hair dressing and milling operators.

The supply of fuel wood and charcoal was mainly operated in the informal market system. The study results from the forestry service division estimates that about 2.5 hectares of off-forest reserve forests are being lost annually to fuel wood supply, charcoal production, agriculture, uncontrolled burning, mining and other factors, with about $80 \%$ of the cleared forest never replanted (Adom-Opare, 2012). The quantities of energy demand and supplied daily are averaged and shown in table 2.

Table 2. Rural Energy Demand and Supply

\begin{tabular}{cccccc}
\hline \multirow{2}{*}{ Energy Form } & \multicolumn{4}{c}{ Demand } & \multirow{2}{*}{ Supply (kg/day) } \\
\cline { 2 - 4 } & \multicolumn{2}{c}{ Residential (Household average) } & \multicolumn{2}{c}{ Commercial } & \\
\cline { 2 - 5 } & $\mathrm{kg} /$ day & GHS/day & $\mathrm{kg} /$ day & GHS/day & \\
\hline Fuel wood & 13.3 & 0.6 & 180 & 4.1 & 175.5 \\
Charcoal & 3.2 & 0.97 & 10 & 1.2 & 125 \\
\hline
\end{tabular}

Source: Adom-Opare, 2012 
Fuel wood demand and supply are in danger of conflicting nexus, the study has revealed. It was realised that, a total of $\sim 176 \mathrm{~kg}$ of fuel wood is available for supply daily, however the demand from both residential and commercial sectors are $\sim 193 \mathrm{~kg}$. There is a daily backlog of $17 \mathrm{~kg}$ required to satisfy both residential and commercial demand. The supply of charcoal was identified as the back up to offset this daily deficiency in fuel wood demand. However, this energy source is expensive compared to fuel wood and it forces households and businesses to push for more fuel wood.

In terms of supply, all the interviewed charcoal burners were using the traditional earth mound method and they did not know of any other method when asked about other more efficient methods like the charcoal kiln and the sealed metal container. This rudimentary method takes an average of about 72 hours (3 days) to complete a single charcoal burning batch. In terms of fuel wood, the survey revealed that, $70 \%$ of the suppliers were either felling trees or hand picking woods for sale. This contributed to the annual forest depletion of about 2.5 hectares (NEMA, 2010).

Another interesting finding that affected demand and supply was the household size and income of household. Taking household fuel wood consumption levels into consideration, the data showed a very strong positive correlation ( $r=0.893$ and $r^{2}=79 \%$ ) between household size and quantity of fuel wood collected daily. Commonly, larger households are expected to increase fuel wood consumption since there is assumed larger demand as well as plenty hands to collect fuel wood. The correlation coefficient of $r=0.893$ emphasised this phenomenon.

On the case on charcoal, this was quite different as the purchasing power of households became the main factor affecting the quantity consumed daily; thus, there was a weak positive correlation ( $r=0.147$ and $r^{2}=2 \%$ ) between household size and the quantity of charcoal consumed daily. When the correlation between household income and charcoal consumption was computed, it revealed a very weak negative correlation $\left(r=-0.069\right.$ and $r^{2}=$ $0.5 \%)$. Though this information is obscure, it is clear enough to say and infer that, the amount of charcoal consumed daily in rural households is very much dependent on household size as well as household income level. Charcoal consumption could be strongly affected by its availability in the area as well as abundance/otherwise of fuel wood sources in the area.

There will be increased pressure and over-exploitation of natural forests for the increasing fuel wood and charcoal demands. Data from the Forestry Services Division responsible for NEMA forest zones indicated that, the off-forest reserves were depleting at an alarming rate. The study was able to identify that, an average of about 104.45 hectares on-forest cover and about 600 hectares off-forest cover have been lost over the past 5 years ${ }^{5}$. Most alarming to this phenomenon was the fact that, the rate of natural growth or forest replenishment had reduced due to increase in average temperature and evaporation (these will be discussed further in the subsequent sections).

\footnotetext{
${ }^{5}$ These are estimates made with the forestry service division and cartographer
} 


\subsection{Climate Change Variables and their Behavior in Rural Communities}

From the study it has been realized that the average weather conditions which make up the climate of NEMA have changed over the past 30 years. The variables that affect climate change may include wind speed, air pressure, relative humidity, precipitation, temperature among others. However, due to time and financial constraints the variables considered are only limited to rainfall, temperature and sunshine and evaporation; over a period of seven (7) years from 2005 to 2011, with additional estimates for the past 30 years being used as the benchmark.

\section{$\underline{\text { Rainfall }}$}

NEMA has over the past decade been seen as the wettest zone in Ghana, with Axim ${ }^{6}$ recording the highest rainfall annually of over $3000 \mathrm{~mm}$. The study showed that, the trend in rainfall was falling from 2005 to 2008 (154.4mm to $130.5 \mathrm{~mm})$ and then climbed up from 2009 to 2010 (145.1mm to $155.6 \mathrm{~mm}$ ) before starting to drop in 2011. Though from 2009, rainfall could be said to increase, it was realized from the survey that, this increase was not near the normal average rainfall over the past decade which stood at over $3000 \mathrm{~mm}$ p.a. and even started dropping again in 2011. Currently, Tarkwa township records the highest average annually rainfall in Ghana, a feat which recently was recorded in NEMA.

\section{Temperature}

The normal average temperature of NEMA for the past decades was $23.5^{\circ} \mathrm{C}$, but over the past 10 to 20 years this has increased significantly. The increase in temperature has now caused the normal temperature to range between $24.9^{\circ} \mathrm{C}$ and $31.2^{\circ} \mathrm{C}$. The study has been able to identify that, temperatures over the seven years under consideration have generally been increasing; see figure 4.9. However, according to the municipal assembly's meteorologist, average temperatures are cooler; ranging between $19^{\circ} \mathrm{C}$ and $22^{\circ} \mathrm{C}$; at night and dawn. It was found out that, this is only the indication of higher temperatures during most parts of the day. The increasing temperatures, an indication of atmospheric warming in the study area, and confirmation of global warming, is a contributing factor to high surface water evaporation rates.

\section{$\underline{\text { Sun Shine and Evaporation }}$}

Over the past decade, sunshine was recorded at an annual average of between 2hours to 2.5hours daily, but since the past 20 to 30 years this has increased to between 5.7hours to 6.1hours. This has also affected water evaporation to increase from a normal average of about $0.02 \mathrm{~mm}$ to about $1.5 \mathrm{~mm}$ over the past 20 to 30 years.

In summary, the discussions above show that, climate change is a phenomenon in NEMA. Increasing temperatures, reduced rainfall regimes, increasing hours of sun shine as well as increase in rate of surface water evaporation are indications of a change in the climate of NEMA. It is known that, these indicators were decades ago more favorable with lower

\footnotetext{
${ }^{6}$ Capital of NEMA
} 
temperatures and high rainfall regimes as well fewer hours of sun shine and smaller amounts of surface water evaporations.

\subsection{Finding the Balance between Rural Energy and Climate Change Impacts - Adaptation}

It is known from literature that climate change would impact energy supply and demand as well as energy use also impact climate change (Adom-Opare, 2012). But, the data presented so far indicates that, it is impossible for methodological justifications to prove a single causal connection between, for example, the level of energy consumed or supplied within a period on one hand and rise in NEMA's mean annual temperature or mean annual rainfall on the other hand. This makes quantification of the linkages between these two phenomena also impossible.

Notwithstanding, it has become clear enough from the issues presented, that, changes in growing conditions have contributed to the fast depletion of biomass (fuel woods and charcoal resources), as well as reduce the prospects for carbon sequestration in forest resources. This could worsen current trends in the depletion of biomass energy stocks in NEMA, which is already depleting at 2.5 hectares annually. Although the traditional energy sources are renewable and may be adaptable to new climate, its heavy dependence might make NEMA's rural areas relatively more sensitive to climate.

\section{Energy Consumption and Climate Change}

Most (98\%) rural communities in NEMA currently consume fuel wood and charcoal for water heating for domestic purposes; and out of this, $86 \%$ and $9 \%$ use fuel wood and charcoal respectively. With increasing average temperatures and its accompanying cooler dawns, households are more likely to increase the energy consumption on water heating as it was identified that water heating was mainly for bathing at early mornings before household members leave for work (mostly farming).

The average daily consumption of fuel wood, which is $13.31 \mathrm{~kg}$, is likely to increase exponentially given the strong positive correlation $(r=0.893)$ between household size and fuel wood consumption. This is so in the case of fuel wood because, majority of the households were using it for water heating and it was deemed cheaper by respondents when compared to charcoal usage. Inferentially, demand for "ice water" will also increase as a result of increasing temperatures causing warmer afternoons; and from the survey, most of the communities were using "ice block" to chill their household water sources since majority (60\%) did not own refrigerators. Energy needs for refrigerating will increase as a result.

In addition, with household and business/industrial energy demand increasing and continue to increase, pressure will be on the natural forests which serve most of these rural communities with fuel wood and charcoal resources. If the further depletion of forests becomes imminent, carbon sequestration will freeze and contribute towards global warming and its consequences.

\section{Energy Supply and Climate Change}

The average daily fuel wood and charcoal supply in the study areas; $175.5 \mathrm{~kg}$ and $125 \mathrm{~kg}$ respectively; are more likely to increase exponentially over the next five to ten years. Based 
on the fact that, over the past five years, fuel wood and charcoal supply had increased by about $80 \%$ to $200 \%$, using logical reasoning for forecasting, over the next five to ten years, fuel wood and charcoal supply could increase to about $351 \mathrm{~kg}$ daily and $250 \mathrm{~kg}$ daily respectively, with all other factors held constant. Looking at this scenario, natural forests, the main source for fuel wood and charcoal, is gradually being extremely exploited.

But falling rainfall patterns coupled with increasing temperatures and longer hours of sun shine, also distorts forest regeneration after felling trees for fuel. Since demand is concentrated heavy on fuel wood and charcoal for domestic and commercial purposes, supply will respond with aggressive destruction of the natural forest and the impacts of the change in climate with respective to falling rainfall and increasing temperature, discussed earlier, will impede growth of depleting forests. The future looks bleak in terms of quantities of available energy stock from the natural forests.

\section{Conclusion}

In summary, although the above discussed scenarios statistically remain speculative, they have provided insights on the nature and orders of magnitude of future scenarios in rural communities. The fact still remains that energy demand is increasing exponentially with supply but the natural forest is not regenerating exponentially. However, the study has been able to attribute this to the indicators of climate change discussed - falling rainfall, increased temperatures, increased daily hours of sun shine and increased evaporation rates.

These extreme weather conditions are affecting energy production and other energy sources like fuel wood and charcoal. Their frequency and intensity are expected to change and this uncertainty is a factor for consideration in energy planning. The balance between rural energy forms and climate change explains the need for rural communities and businesses to adapt and diversify their energy needs. Policy makers and leaders should start looking at ways to provide a diversified energy source to rural and urban communities due to the heavy dependence on wood based fuels.

As new energy technologies and investment emerge, rural energy systems for the future will differ from that of today in uncertain ways. Consequently, adequate planning and research are needed to guide decision making to manage the risks and opportunities that climate change will introduce in the future.

\section{References}

Blaikie, N. (2003). Analyzing Quantitative Data (pp. 12, 52, 65). London: SAGE Publications Ltd.

Burns, R. (2000). Introduction to Research Methods. Frenchs Forest, Pearson Education. CDU Library: 370.72 Burn.

Cameron, C., (2011). Climate Change Financing and Aid Effectiveness; Ghana Case Study Revised. Agulhas Applied Knowledge, Accra Ghana. 
Cole, S., \& McCarthy, L. (2014). Long-term global warming trend sustained in 2013. [Online] Available: http://climate.nasa.gov/news/1029/ (January 30, 2014).

Durante, D., \& Sneller, T. (2005). Issue Brief: Energy Security (pp. 1-4). New York: Ethanol across America.

Energy Commission. (2011). 2011 Energy (Supply And Demand) Outlook for Ghana. Accra.

Energy Commission, (2012). Ghana Action Plan for Sustainable Energy for all by 2030. Accra, Energy commission.

Ghana Statistical Service. (2012). 2010 Population and Housing Census; Summary report of final results (p. 4). Accra: Sakoa Press Ltd.

IPCC. (1998). The Regional Impacts of Climate Change: An Assessment of Vulnerability. Special Report of IPCC Working Group II [Watson, R.T., M.C.

Inkoom, D. K. B. (2011). Climate Change and Poverty Reduction in Ghana: Issues and Implications for Policy. Regional Development Dialogue (RDD), 32(1), 35-48.

IPCC. (2001). Climate Change 2001: Impacts, Adaptation and Vulnerability. IPCC Working Group II, Third Assessment Report. [McCarthy, J.J., O.F. Canziani, N.A. Leary, D.J.

IPCC, (2009). IPCC Expert Meeting on Detection and Attribution Related to Anthropogenic Climate Change. Geneva, Switzerland, 14-16 September 2009. [Stocker, T., Field, C., Dahe, Q., Barros, V., Gian-Kasper P., Tignor, M., Midgley, P., and K. Ebi (eds.)] Geneva: IPCC Working Group I Technical Support Unit.

KITE. (2005). Development and Energy in Africa; Ghana country report. Accra, KITE.

KITE. (2008). Rural Sustainable Energy Systems in Ghana. Accra, KITE.

Ministry of Environment Science and Technology, (2010). Ghana goes for green growth. National engagement on climate change. Discussion document, Ghana.

Nkum Associates. (2003). How to do guide on District Poverty Profiling and Mapping. Accra: Local Government and Poverty Reduction Support Programme (LGPRSP).

The World Resources Institute, 2010. [Online] Available: http://cait2.wri.org (May 30, 2011).

Zinyowera, \& Moss R. H. (Eds.). Intergovernmental Panel on Climate Change (pp. 5-17). Cambridge University Press, Cambridge, United Kingdom and New York.

\section{Copyright Disclaimer}

Copyright for this article is retained by the author(s), with first publication rights granted to the journal.

This is an open-access article distributed under the terms and conditions of the Creative Commons Attribution license (http://creativecommons.org/licenses/by/3.0/). 